\title{
The Role of Education on Small-scale Mining for Sustainable Development A case of Banda/Nkwanta Community in the Bole District-Ghana
}

\author{
Article by Nestor Naabulee Nasage \\ Managing Consultant - Uni-Sky Holdings Limited Sunyani Ghana \\ Ph.D in management student, Texila American University, India, Guyana campus \\ Email:nasagenestor@yahoo.com
}

\begin{abstract}
The activities of small scale miners in Ghana have had negative effects on the environment and this has hampered security within the environment. The study seeks to assess the role of education on small-scale mining for sustainable development in the Banda/Nkwanta community in the Bole District, the Northern part of Ghana. Small scale mining operations have been a major cause of most of the negative environmental impacts in most parts of Ghana. This activity has now found its way to the Northern part of Ghana which is a serious canker for sustainable development. The environmental effects of these activities are higher because most of the activities are not coordinated and monitored by authorities especially in the Northern part of Ghana. The methods of mining applied by operators determine the severity of threat to environmental security. The chemical method of processing gold is a severe health hazard, especially the amalgamation with mercury. Small scale mining activities have a lot of negative impacts on agricultural activities, the major occupation and source of livelihood for the people. It is recommended that Government and its agencies should encourage the illegal small-scale operators to formalize their operations in order to be accessible for supervision. The issuance of licenses and permit for surface mining should be reduced and most of these companies should be encouraged to explore the underground mining method with appropriate techniques and skills that meet international best practices. The Bole District Assembly should enforce environmentally friendly bye-laws, education and comprehensive environmental protection measures.
\end{abstract}

Keywords: Education, small-scale Mining, Sustainable development.

\section{Type of paper: research paper}

\section{Background}

"Banda Nkwanta was formerly called 'Dua'. The first settler was a Sissala man who was driven down by war in the north and was later joined by a Dagarti friend. They decided to settle to do farming and hunting. The exact date the community was established is not known but speculated to be before the Second World War. The name Dua was changed to 'Nkwanta' (meaning junction in Akan) because it became a trading junction where cattle were bought and sold. It was a junction to Banda."

Ghana's major occupations in recent times is Mining of minerals. According to some scholars such as Monika Weber-Fahr and John Strongman, large-scale mining generates about 85 percent of the world's nonfuel minerals and more than 95 percent of the world's total mineral production. The mining industry in Ghana has largely been transformed from a fragmented industry characterized by small-scale operations to one dominated by a relatively concentrated group of multinational corporations managing massive operations in increasingly remote areas. Notwithstanding, the current surge in small scale mining in Ghana, popularly known as "Galamsey," which can literary be translated as 'gather and sell' cannot be underestimated. Over the years for instance, over 650 registered small-scale mining groups were engaged in the mining of gold, diamonds and industrial minerals in Ghana. This increasing scale and intensity of small scale type of mining operations have not gone unnoticed and unconcerned by the communities that host them. These communities - often rural, indigenous and poor - are particularly vulnerable to the 
DOI: $10.21522 /$ TIJAR.2014.04.02.Art019

ISSN: $2520-3088$

environmental and social impacts generated by the miners. The activities of small scale miners in developing countries such as Ghana to a large extent have had major effects on the environment. The most affected resources have been water bodies, land and forest resources.

The Northern part of Ghana which lacks much vegetation is also now one of the hotspots of small scale mining. Banda /Nkwanta the area selected for this study is home to significant mining activity, mainly on gold. It is one of the communities most affected by activities of small scale miners in the Northern part of Ghana.

For many centuries, the small-scale mining of precious minerals has made a significant impact on the socio-economic lives of people and communities involved directly or indirectly in the sector (Kesse, 1985; Hilson, 2002a). In Ghana, the precious minerals mined at the small-scale level are gold and diamonds. Since the regularization of small-scale mining in 1989, over 1.5 million troy ounces of gold and 8.0 million carats of diamonds have been produced by the sector (Ghana Minerals Commission, 2004). Due to its labor intensity, small-scale mining operations generally generate significant employment avenues, especially in remote rural areas where alternative job opportunities are scarce and low paying. However, production of these minerals has been at a cost to the environment and there is the need to develop the sector in a sustainable manner.

Sustainable development of minerals and other natural resources has been endorsed as a global management and development strategy and environmental, economic and social developments have been highlighted as the three pillars of sustainable development and their integration is encouraged WCED, (1987); Anon, (1992). There are, however, several arguments about the applicability of these concepts in the minerals industry, especially the small-scale minerals industry, since minerals are non-renewable resources that are subject to exhaustion in the course of production. The exhaustible nature of mineral resources places a limit on growth of these industries and hence their sustainability Lele (1991); Mikesell, (1994); Traore, (1997); Ednie, (2002); Anon, (2002).

In Ghana, there is an ongoing discussion by stakeholders in the mining industry on measures to mitigate the negative effects of small-scale gold and diamond mining and to help the industry to develop in a sustainable manner Yakubu, (2002); Hilson, (2002). This paper is a contribution to the debate. It focuses on how the general concepts of education for sustainable development can be applied specifically to the small-scale gold and diamonds mining industry in Ghana. Sustaining the sector is considered in the context of the mineral supply process, environmental and health implications, and the socioeconomic realities of the affected areas

\section{Methodology}

The type of research strategy used for this work was exploratory, which was a case study because the study has been undertaken on a small scale and within a limited time to investigate the impact of education on small scale mining for sustainable development in the Band/Nkwanta community. A research design is a kind of blueprint that guides the researcher in his or her investigation and analyses (Onwumere, 2009), the study relies on interviews and questionnaire to obtain the needed information.

The target population of this study was community members and aliens living in Band/Nkwanta in the Bole District. This is due to proximity, time constraints, cost involved. The researcher depended on opinion leaders' prerogatives to encourage other commutants to participate effectively and complete all the items seriously in order to get accurate results.

To meet the objectives set and consequently avoiding ambiguous interpretations coupled with time constraints, the sample was composed of 83 indigents of the community and opinion leaders in the Bole District. Convenience sampling technique was used in the selection of the respondents required to conduct this research and was supported by purposive sampling. Eighty-three questionnaires were administered. 


\section{Findings}

The table below shows the questionnaire administered and their results presented.

Table 1. Response to questionnaire

\begin{tabular}{|l|l|l|}
\hline Questionnaire & Respondents & Percentage (\%) \\
\hline Questionnaire returned & 80 & 97 \\
\hline Questionnaire not returned & 2 & 2 \\
\hline Questionnaire spoiled & 1 & 1 \\
\hline Total & 83 & 100 \\
\hline
\end{tabular}

Source: Researcher's field work (august, 2017)

From 3.1 above, it can be seen that most of the respondents were able to return their questionnaires. With the total of eighty-three (83) questionnaire administered, eighty (80) respondents returned their completed questionnaire to the researcher representing 97\%. two (2) of the remaining were not returned and this represented $2 \%$. The remaining one (1) spoiled representing $1 \%$. The high rate of respondents returning their questionnaires explained the fact that, there was a favorable response to the questionnaires.

Again, from the field survey, majority of the respondents out of total respondents of 80 were males representing $85 \%$ response rate.

Also from the field survey, 61 of respondents representing as much as $76 \%$ of the total respondents were between the ages of 20 and 40.10 of the remaining respondents representing 13 percent were between the ages of 41 and 60. Only 9 of the remaining respondents were between the ages of 61years and above and this represent $11 \%$ of the total respondents. This indicates that majority of the respondents were between the ages of 20 and 40

The marital status of the respondents also indicates that about 15 percent were married whilst 65 percent were single. This means that the majority of the respondents were single.

From Table 4.5 below, 55 of the respondents representing $69 \%$ of the total population were secondary school leavers. 10 of the remaining respondents were diploma holders and this represents $13 \%$ of the total respondents. Only 15 of the remaining respondents had first degree and this represent $18 \%$ of the total respondents.

This indicates that majority of the respondents had completed secondary education.

Table 2. Educational level

\begin{tabular}{|l|l|l|}
\hline Level of education & $\begin{array}{l}\text { Number of } \\
\text { respondents }\end{array}$ & Percentage (\%) \\
\hline Secondary education & 55 & 69 \\
\hline Diploma & 10 & 13 \\
\hline First degree & 15 & 18 \\
\hline Total & 80 & 100 \\
\hline
\end{tabular}

\section{Researcher's field work (August 2017)}

The researcher wanted to know the occupation of the respondents and this is represented on table 3 below.

56 percent of the respondents were farmers whilst 10percent were miners. Other occupations include traders which constitute 5 percent, 18 percent fishermen and 2 percent public service workers this indicate majority of the respondents were females (see table 3 below). 
DOI: $10.21522 /$ TIJAR.2014.04.02.Art019

ISSN: $2520-3088$

Table 3. Occupation

\begin{tabular}{|l|l|l|}
\hline Occupation & $\begin{array}{l}\text { Number of } \\
\text { respondents }\end{array}$ & Percentage \\
\hline Farmers & 45 & 56 \\
\hline Traders & 5 & 6 \\
\hline Fishermen & 18 & 23 \\
\hline $\begin{array}{l}\text { Public service } \\
\text { workers }\end{array}$ & 2 & 2 \\
\hline Miners & 10 & 13 \\
\hline Total & 80 & 100 \\
\hline
\end{tabular}

Researcher's field work (August, 2017)

\section{Awareness of mining activities}

The researcher wanted to know whether respondents are aware of small scale mining activities in the community. Some key information was obtained during the course of the primary survey. These have been analyzed below.

From the field survey, all respondents claim that they have heard and seen small scale operations going on with groups sometimes made up of strangers from other places. Thus, the awareness on small scale mining activities among the people is very high as presented in the Table $\mathbf{4}$ below.

Table 4. Awareness of small scale mining

\begin{tabular}{|l|l|l|}
\hline Responds & Number of respondents & Percentage (\%) \\
\hline Yes & 80 & 100 \\
\hline Total & 80 & 100 \\
\hline
\end{tabular}

\section{Researcher's field work (August, 2017)}

\section{Illegal small-scale mining activities}

Two categories of small scale mining activities occur in the area. One category is the registered smallscale operators and the other category is the unregistered ones who carry out mining activities without licenses or any permit. The second category of miners is referred to as the "galamsey". The responses from the field indicate that there is high incidence of illegal mining activities. All of the respondents admitted that illegal mining activities are rampant as presented in the table 5 below.

Table 5. Illegal mining activities

\begin{tabular}{|l|l|l|}
\hline Responds & Number of respondents & Percentage (\%) \\
\hline Yes & 80 & 100 \\
\hline Total & 80 & 100 \\
\hline
\end{tabular}

\section{Researcher's field work (August, 2017)}

\section{Methods of mining}

The researcher wanted to find out the methods of mining implored in Banda Nkwanta community and whether the methods of mining applied by miners have profound effects on the environmental security. The results indicate confirming the following type of methods of mining in the Banda/Nkwanta Community: surface mining, Underground mining, dredging, galamsey method. Galamsey method is the highest method being used. (See table 6 below). 
Table 6. Mining methods

\begin{tabular}{|l|l|l|}
\hline Responds & Number of respondents & Percentage (\%) \\
\hline Underground mining & 10 & 13 \\
\hline Dredging & 15 & 19 \\
\hline Galamsey method & 55 & 68 \\
\hline Total & 80 & 100 \\
\hline
\end{tabular}

Researcher's field work (August 2017)

Negative impacts of small-scale mining on farming activities

Again, the researcher wanted to know if mining activities especially small-scale operations in the Banda/Nkwanta community have proven to exert negative impact on farming activities in the area. The perceptions of the people are summarized below.

Table 7. Clearing of vegetation

\begin{tabular}{|l|l|l|}
\hline Responds & Number of respondents & Percentage (\%) \\
\hline Yes & 80 & 100 \\
\hline Total & 80 & 100 \\
\hline
\end{tabular}

\section{Researcher's field work (August, 2017)}

As a result of mining activities especially those activities which are carried out illegally, the environment is losing most of its natural vegetation. As part of the mining activities, forests are cleared and burnt to give space for miners to dig and scoop the soil deep down to minerals to be accessed. This has resulted in land degradation, deforestation and loss of top soils for agricultural purposes. Respondents of the field survey in table above have confirmed that small scale-operators burn and clear the vegetation and dig for mineral in Banda/Nkwanta.

\section{Damage of agricultural landscape}

The researcher wanted to know if Small scale mining operations lead to destruction of the environmental landscape and hence making farming unsuitable. This is seen in table below:

Table 8 Damage of agricultural landscape

\begin{tabular}{|l|l|l|}
\hline Responds & $\begin{array}{l}\text { Number of } \\
\text { respondents }\end{array}$ & Percentage (\%) \\
\hline Yes & 80 & 100 \\
\hline Total & 80 & 100 \\
\hline
\end{tabular}

\section{Researcher's field work (August, 2017)}

From the table, all respondents claimed that small scale mining activities cause destruction of the landscape to render it unsuitable for agricultural purposes

\section{Competition between mining and farmlands}

Currently in Banda/Nkwanta community, a stern competition is on-going between the small-scale miners/galamseyers and the farming communities for arable land. This fact was confirmed by 88 percent of the respondents as indicated in the table 9 below. In actual sense farming and other agricultural activities are seriously affected by dangerous activities of the miners in the community. 
DOI: $10.21522 /$ TIJAR.2014.04.02.Art019

ISSN: $2520-3088$

Table 9.

\begin{tabular}{|l|l|l|}
\hline Responds & Number of respondents & Percentage (\%) \\
\hline Yes & 70 & 88 \\
\hline No & 10 & 12 \\
\hline Total & 80 & 100 \\
\hline
\end{tabular}

Researcher's field work (August, 2017)

Farmers deprived of farmland

In most cases farmers are being forced to sell their farm and the land to mining operators through the aid of the traditional rulers and sub chiefs. 63 percent of the respondents' states that farmers in the community have been deprived of farmland for farming, 25 percent do not support that statement whilst 12 percent do not know of such incident ongoing in the community as presented in table 10

Table 10. Farmers deprived of farmland

\begin{tabular}{|l|l|l|}
\hline Responds & $\begin{array}{l}\text { Number of } \\
\text { respondents }\end{array}$ & Percentage \\
\hline Yes & 50 & 63 \\
\hline No & 20 & 25 \\
\hline Do not know & 10 & 12 \\
\hline Total & 30 & 100 \\
\hline
\end{tabular}

\section{Researcher's field work (August, 2017)}

\section{Addressing environmental issues by government}

Most of the respondents were of the view that the district assembly does not take environmental issues serious. According to them, the assembly does not undertake any proper steps to check and address the adverse effect of small scale mining on environment. 88 percent of the respondents claimed that environmental issues were not addressed by the Assembly whilst 12 percent claimed that the assembly put in place proper mechanisms in addressing such issues (See table 11).

Table 11. Addressing environmental issues by district assembly

\begin{tabular}{|l|l|l|}
\hline Responds & Number of respondents & Percentage \\
\hline Yes & 70 & 88 \\
\hline No & 10 & 12 \\
\hline Total & 80 & 100 \\
\hline
\end{tabular}

\section{Researcher's field work (August, 2017)}

The researcher wanted to know if Government task forces operating in the southern part of Ghana have been deployed to the Northern part of Ghana to curb illegal mining for sustainable development. The government has constituted a task force known as "operation vanguard" to stop illegal mining in the communities for sustainable development. The president in one of the forums put his presidency on the line to curb illegal mining. From the field survey in table3.15, these task forces are only operating in the southern part of Ghana and hence not in the Northern part of Ghana where Banda/Nkwanta community is located. From the table 12 below, all respondents were of the view that no Government task force has come around to stop them from illegal mining. 
Table 12. Addressing illegal mining issue by Government task forces

\begin{tabular}{|l|l|l|}
\hline Responds & $\begin{array}{l}\text { Number of } \\
\text { respondents }\end{array}$ & Percentage \\
\hline No & 80 & 100 \\
\hline Total & 80 & 100 \\
\hline
\end{tabular}

\section{Researcher's field work (August, 2017)}

\section{Small scale mining causes major health problems:}

Small scale mining activities cause profound health problems especially through the use of mercury and cyanide in the amalgamation process to collect gold particles from sediments. This process leads to discharge of excess chemicals into the land and water resources. In table 13, a total of 70 out of 80 respondents stated that small scale mining causes serious health problems.

Table 13. Small scale mining causes major health problems

\begin{tabular}{|l|l|l|}
\hline Responds & $\begin{array}{l}\text { Number of } \\
\text { respondents }\end{array}$ & Percentage \\
\hline Yes & 70 & 88 \\
\hline No & 10 & 12 \\
\hline Total & 80 & 100 \\
\hline
\end{tabular}

\section{Researcher's field work (August, 2017)}

\section{The danger of the pits after small scale operation}

94 percent of the respondents believed the pits dug by small scale operators normally filled with stagnant water and serve as breeding grounds for mosquitoes and reptiles. This usually causes diseases and hence threat to human settlement in the community. This is represented in table 14 below:

Table 14. The danger of the pits after small scale operation

\begin{tabular}{|l|l|l|}
\hline Responds & $\begin{array}{l}\text { Number of } \\
\text { respondents }\end{array}$ & Percentage \\
\hline Yes & 75 & 94 \\
\hline No & 5 & 6 \\
\hline Total & 80 & 100 \\
\hline
\end{tabular}

\section{Researcher's field work (August, 2017)}

The researcher wanted to know if respondents have any education on the effect of illegal mining and how this can affect sustainable development in the community and the country at large. This is represented in the table 15 below:

Table 15. Education on the effect of illegal mining

\begin{tabular}{|l|l|l|}
\hline Responds & $\begin{array}{l}\text { Number of } \\
\text { respondents }\end{array}$ & Percentage \\
\hline Yes & 1 & 1 \\
\hline No & 79 & 99 \\
\hline Total & 80 & 100 \\
\hline
\end{tabular}

\section{Researcher's field work (August, 2017)}

From table 3.18 above, 79 out of the total respondents agree that they have no education on the effect of illegal mining and how this affects sustainable development. This represent 99 percent response rate. The 
DOI: $10.21522 /$ TIJAR.2014.04.02.Art019

ISSN: $2520-3088$

remaining 1 agree to have had education on the effect of illegal mining and this represent 1percent response rate. This therefore indicates that majority of the respondents have no education on the effect of illegal mining.

\section{Discussions}

The survey revealed that there is high incidence of illegal mining activities in Banda/Nkwanta community. The respondents admitted that illegal mining activities are high in the community.

Secondly, Galamsey method of mining is the highest method being used in Banda/Nkwanta. Respondents of the field survey confirmed that small scale-operators burn and clear the vegetation and dig for minerals.

Majority of respondents also claimed that small scale mining activities cause destruction of the landscape to render it unsuitable for agricultural purposes. Respondents also claim there is Competition between mining and Farmlands hence farmers in the community have been deprived of farmland for farming.

Furthermore, Majority of the respondents claimed that environmental issues were not addressed by the District Assembly. Respondents were of the view that no Government task force has come around to stop them from illegal mining

Majority of respondents were of the view that Small scale mining activities cause profound health problems especially through the use of mercury and cyanide in the amalgamation process to collect gold particles from sediments, respondents believed the pits dug by small scale operators normally filled with stagnant water and serve as breeding grounds for mosquitoes and reptiles, and this usually causes diseases and hence threat to human settlement in the community.

The study also revealed that respondents who have no education on the effect of illegal mining were the majority.

\section{Conclusions}

It's concluded that, there is negative effects of small-scale mining on farming activities in Banda/Nkwanta that affects sustainable development. There are also health hazards caused by mining to the local communities in Banda/Nkwanta. The methods of mining activities applied by mining operators determine the severity of the threat to environmental security. The methods of mining activities employed in the mining localities in Ghana specifically Banda Nkwanta, is the galamsey method of mining. victims of small scale mining activities have no education on the effects of illegal mining and their activities contribute to unsustainable development. Government has taken steps to address illegal mining activities but only limited to southern part of Ghana. Education therefore has an important role to play in curbing illegal mining in the Band/Nkwanta community and this will lead to sustainable development.

\section{Recommendations}

This study has carried out a thorough and candid assessment of the impact of education on small scale mining for sustainable development in the Banda/Nkwanta community as a case study. Based on the findings and conclusions of this study, the following recommendations were made:

Government and its agencies should encourage the illegal small-scale operators to formalize their operations in order to be accessible for supervision, coordination and monitoring. The registered and legal large and small-scale mining operators should create employment avenues for the local people through training in order to mainstream them since most of the illegal and smaller operators (galamseyers) were believed to be natives and members of the mining communities who usually go into illegal practices for livelihood and this group see their illegal activities as their right to the land.

The issuance of licenses and permit for surface/ open cast mining should be reduced and most of these companies should be encouraged to explore the underground mining method with appropriate techniques and skills to meet international best practices. This could solve two problems: first the issue of competition and conflict between miners and farmers over arable land will be minimized, and secondly, because the underground mining is labour intensive most of the subsistent illegal miners could be employed into this. 
The Government together with the Bole district where Banda/Nkwanta is located, must be able to require the mining operators to abide and ensure proper and comprehensive environmental protection measures. The Government should establish an independent and effective oversight mechanism to monitor small scale mining companies to fully comply with national and international health and environmental protection standards.

The government and the Bole District Assembly should set the laws and by laws on the mining activities in the district in order to allow most part of the forest and vegetation to be reserved for agricultural purposes especially for both food and cash crop cultivation.

The anti-galamsey task forces being set by the Government should extend their operations to the Northern part of Ghana where these illegal mining activities are going on.

It is also recommended that, there should also be stern and serious attempts to restore the deforested and degraded lands including covering and refilling pits and trenches developed during excavation and extraction processes of the small-scale miners in the communities of the District.

\section{Acknowledgement}

All praise and gratitude be given to God Almighty for giving me such a great strength, patience, courage, and ability to complete this project. Although any learning activity is a lonely personal, it requires help, support and encouragement of others to be successful. "Just as an eagle could not soar without the invisible strength of the wind', I could not have arrived at this place without all the invisible hands that provided me that strength. I would like to present my humble appreciation and gratefulness to all the people who made this journey possible especially TAU, and the Banda/Nkwanta community. I am indebted to those who knowingly and unknowingly were so helpful and important in the difficult moments. Firstly, my deepest appreciation goes to Ms. Yasotha S. who has provided unlimited amount of encouragement and professional support. She valued my commitment to self and lifelong learning and all the while supporting my academic endeavors. Thank you, Ms. Yasotha for your positive attitude and outlook; you are an incredible coordinator and an outstanding leader.

\section{References}

[1]. Akabzaa, T. and Darimani, A. (2001), Impact of Mining Sector Investment in Ghana: A case study of the Tarkwa Mining Region, A Draft Report, www.saprin.org/ghana/research/gha_mining.pdf.

[2]. Akabzaa TM (2000). Boom and Dislocation: The Environmental and Social Impacts of Mining in the Wassa West District of Ghana (Accra: Third World Network Africa).

[3]. Akabzaa, T.M., Seyire J.S., Afriyie, K. (2007) - The Glittering Façade: Effects of Mining Activities on Obuasi and its Surrounding Communities. (Accra: Third World Network Africa).

[4]. AfDB Annual report (2009) Overview of the Macroeconomic Situation Economic Outlook for Africa and the Role of the Bank.

[5]. Brooke D. Barton (2005) - A Global/Local Approach to Conflict Resolution in the Mining Sector: the case of the Tintaya dialogue table.

[6]. Bernstein, P.L. (2004) - The Price of Gold - http://www.ethicalmetalsmiths.org/ThePRICEofGOLD.pdf

[7]. Camillo Premoli (2011) - African Gold: Potential, Problems and Opportunities. Pdf accessed on 1st august, 2014 at $1: 29 \mathrm{am}$.

[8]. Carter (2012) - Digging for Frameworks, Theories, and Models in Environmental Policy \& Management, the Workshop in Policy Process Research and Environmental Affairs Working Group Seminar.

[9]. Daniel F. (2009). Avoiding Mine-Community Conflict: From Dialogue To Shared Futures Donkor, A. K,. Nartey, V. K., Bonzongo, J.C., and D. K. Adotey (2006) - Artisanal Mining of Gold with Mercury in Ghana.

[10]. Garvin, T., Mcgee, T.K., Smoyer-Tomic, K. E. and Aubynn, E.A. (2009) 'Community - company relations in gold mining in Ghana', Journal of Environmental Management, Vol. 90: 571 - 586.

[11]. Gavin H., (2001) - A Contextual Review of the Ghanaian Small-scale Mining Industry.

[12]. Ghana country paper (2010) The 18th Session of the United Nations Commission on Sustainable Development (UNCSD) in May 2010. 
DOI: $10.21522 /$ TIJAR.2014.04.02.Art019

ISSN: $2520-3088$

[13]. Government of Ghana (2010) - A Report on Ghana's Mining Sector for the 18th Session of the UN Commission on Sustainable Development.

[14]. Halina W. (2009) - Resource nationalism and sustainable development: a primer and key issues.

[15]. Heikkila, T., P. deLeon, P. Stretesky, C. Weible, A. Madden, S. Gallaher, S. Huss, G. Fidelman, and D. Hilson, G., (2002) - Promoting sustainable development in Ghanaian small-scale gold mining operations, the Environmentalist, 22, 51-57.

[16]. Kitula, A.G.N. (2005). The environmental and socio-economic impacts of mining on local livelihoods in Tanzania: A case study of Geita District. Journal of Cleaner Production 14 (2006) 405-414.

[17]. Kessey, K. D., Arko B. (2013) Small Scale Gold Mining and Environmental Degradation, in Ghana: Issues of Mining Policy Implementation and Challenges, Journal of Studies in Social Sciences ISSN 2201-4624 Volume 5, Number 1, 2013, 12-30.

[18]. KPMG (2013) - Mining in Africa towards 2020.

[19]. Milton F (1970) - The Social Responsibility of Business is to Increase its Profits. The New York Times Magazine, September 13.

[20]. Mining sector report (2010) - Ghana's Country Paper on UNCSD 2010.

[21]. Miranda M et al, (2005) - Framework for Responsible Mining: A Guide to Evolving Standards.

[22]. Monika W, John E. Strongman, Ramani K., Gary M., and Christopher S., - Macroeconomic and Sectoral Approaches of mining.

[23]. Nita G, Melvin H, and Ryan C., (2010), the cost of Gold - communities affected by mining in Tarkwa Region of Ghana.

[24]. Paul C. Stern (2000) - Toward a Coherent Theory of Environmentally Significant Behavior

[25]. Stephen Y (2008) Surface mining and its socio-economic impacts and challenges in Tarkwa, Ghana. The Southern African Institute of Mining and Metallurgy.

[26]. Utting, P. (2000) - Business Responsibility for Sustainable Development. United Nations Research Institute for Social Development. Occasional Paper No. 2.

[27]. Victoria M (2009), - The Role of Corporate Social Responsibility on Sustainable Development: A Case Study of the mining community in the Obuasi municipality. Master Thesis at the University of Agder, Kristiansand.

[28]. Weber-Fahr, M., Craig A., Leo M. and J.E. Strongman (2002). An Asset for Competitiveness: Sound Environmental Management in Mining Countries. Mining and Development Series. Washington, D.C.: World Bank/IFC.

[29]. World Economic Situation and Prospects (2013) - Update as of mid-2013.

[30]. Yelpaala, K. (2004), Mining, Sustainable Development and Health in Ghana: The Akwatia Case Study, Brown University, U.S.A, and March.

[31]. Yelpaala, K., Ali, S. H. (2005) 'Multiple scales of diamond mining in Akwatia, Ghana: addressing environmental and human development impact', Resource Policy, Vol.30: 145 -155. 